\title{
Keeping it in the family: partnerships between Indigenous and Muslim communities in Australia
}

\author{
Peta Stephenson
}

\begin{abstract}
Aboriginal people and Torres Strait Islanders with Muslim forebears have a connection to Islam that tends to be culturally rather than scripturally based. Born and raised in Darwin in the late 1960s, Indigenous-Malay descendant Sam Ahmat, for instance, describes her family's lineage in these terms: 'We've got Malay, Torres Strait, Mohammed and Aboriginal'. ${ }^{1}$ For Sam, self-identification as a so-called 'Mohammedan' (or Muslim) has very little, if anything, to do with religion. It is primarily an expression of kinship. Assan (Ken) O'Shea is another case in point. Growing up on post-war Thursday Island with his Muslim Malay (adoptive) grandparents, he notes that his grandparents were 'Mohammedans and that's the most important thing', explaining, 'for me, that's my Muslim religion, and that's my Muslim background' . ${ }^{2}$ Evidently, kin-based identification of this kind sharply differs from that associated with formal conversion to Islam. For convenience we might differentiate it from conversion by calling it kinversion, defining this as the phenomenon widespread among people of AboriginalMuslim descent of invoking Islam as a marker of family continuity and identity.
\end{abstract}

This article forms part of a larger study based on interviews conducted with descendants of Aboriginal-Afghan and Indigenous-Malay unions that explores the growing phenomenon of Indigenous Australians' identification with Islam. Its object is to draw attention to a legacy of religious conversion that is usually left out of conversion studies - an identification with Islamic values that is not formal but familial. Any cross-cultural accommodation can involve kinversion, and the term is not put forward here to suggest that my interviewees' experience is unique. However, it is the case that the double marginalisation Indigenous people and Muslims experience in Australia makes kinversion particularly significant. Involving an active rather than passive identification, kinversion becomes in these circumstances a mechanism of identity formation that involves sophisticated negotiations across cultural and power differences, across gender and generations. It represents a mode of social behaviour that combines resilience and respect, an ability to secure social cohesion against the odds whilst allowing for the co-existence of incommensurable historical and human realities.

1 Sam Ahmat in interview with the author, 17 December 2007, Darwin, Northern Territory.

2 Ken O'Shea in interview with the author, 16 March 2008, Caboolture, Queensland. 
Kinversion, it is proposed here, is a powerful means of creating social cohesion, and particularly warrants recognition in a time when the rhetoric of the 'clash of civilisations' devalues ordinary sociability and the creative ways in which individuals negotiate their religious and cultural identities. The phenomenon of Muslim kinversion amongst Australians of Indigenous descent is rooted in history. It emerges from an experience of legislative and institutional segregation, and in its resistance to the racism inscribed in this, constitutes a powerful counter-conviction: that people of different racial, cultural and national backgrounds can co-exist.

It is also important in what follows to differentiate the data of the historical record from that furnished by oral history - they are related but serve different purposes and are not necessarily substitutable. Aboriginal-Afghan and Indigenous-Malay descendants might not be familiar with the full historical circumstances behind the founding alliances that they regard as integral to their present-day identity. At the same time the very phenomenon of kinversion attests to the long shadow that colonial history casts, and all of my interviewees are acutely aware that a long-term and systemic racism has shaped their inheritance, even if the primary purpose their self-narrations serve is the performative one of self-production here and now.

With this methodological caveat, the first part of the article is historical. Kinversion is the result of long-term and widespread contact between Muslims (almost invariably men) and those (almost entirely women) of Aboriginal and Torres Strait Islander background. The 'kinverts' discussed in this paper are descendants of either 'Afghans' or 'Malays', two major sources of labour in the late nineteenth and early twentieth centuries that were almost entirely Muslim in origin and/or conviction. My object in the first section is not to rehearse the history of their encounter with Indigenous Australia - a growing number of accounts of these cross-cultural entanglements now exists - but to extract from that scattered literature some salient cultural and historical experiences common to both immigrant and Indigenous communities that may have facilitated the forging of cross-cultural alliances. The argument here is that these perceived cross-cultural convergences fostered attitudes of mutual tolerance and accommodation whose legacy is still evident in the phenomenon of kinversion.

The balance of the article describes the social impact of these historical events through the lens of family history. Within the family, exposure to Indigenous and, of course, non-Indigenous Australian cultures is perceived to have brought about a new self-consciousness: immigrant Muslims fathering families in Australia had, perhaps for the first time, to justify their faith. In some but not all cases, this revealed a capacity for tolerance that family descendants highly regard. In terms of the extra-familial importance of these cross-cultural marriages, this is seen in the formation of communities that were multicultural long before that term came into wide circulation. The final section seeks to recuperate the agency of the Indigenous women who embarked on new lives with Muslim men: again, through oral family history, these women are perceived to have exercised considerable ingenuity and sophistication as they negotiated their way 
between multiple, and sometimes conflicting, ethical and social expectations. As the article shows, the admired behaviour of the interviewees' forebears is inseparable from the interviewees' goal of finding and sustaining distinctive identities for themselves.

\section{Historical background}

The first Muslims to settle permanently in Australia were the so-called 'Afghan' cameleers. The camel handlers were usually members of nomadic clans that travelled across the border between Afghanistan and India, but when they arrived in Australia they were indiscriminately lumped together as Afghans or 'Ghans', regardless of whether they came from Afghanistan or the northwestern frontier district of the Indian sub-continent (now Pakistan). ${ }^{3}$ Between the 1860s and 1920s, an estimated 2000 to 4000 camel men (no official records were kept) provided a vital lifeline for the developing continent. ${ }^{4}$ With their strings of camels the Afghans transported food, building materials, furniture and equipment to isolated stations, mines and government camps, returning with baled wool, ore and other commodities bound for southern or international markets. By the 1930s, when the advent of motorised transport into the interior of Australia heralded the demise of the camel industry, Afghans had covered about three-quarters of the continent and their camels had carried goods in every mainland state except Victoria. ${ }^{5}$

While Afghan camel handlers carted goods throughout the dry heart of the continent, Malay indentured labourers worked in the pearl-shelling grounds off the Western Australian, Northern Territory and Queensland coasts. Like 'Afghan', 'Malay' is another all-encompassing term. It does not refer to the Malays of present day Malaysia, but was used in nineteenth and twentieth century northern Australia to refer to those who came from Singapore, Java, Timor, Kupang, Sulawesi and elsewhere in the Indonesian Archipelago. 6 The Malays also began arriving in Australia from the 1860s but, unlike the Afghan cameleers, demand for their labour continued until the late 1960s. The pearlshelling industry wound down from the post-Second World War period, but many Malays who arrived here as young men in the late 1950s and 1960s remain in Australia. A significant number of Muslim Malays married local Indigenous women and today there are many Indigenous-Malay people in the Torres Strait, Darwin, Broome and elsewhere in the Top End.

At least three conditions might have influenced the formation of IndigenousMuslim partnerships that lay the foundations of kinversion. These are, first, general cultural convergences. Second, the comparable lifestyles of Malay and north Australian Indigenous communities and of Afghan and desert dwelling

3 Stevens 1993: 49; Jones and Kenny 2007: 9; Loois 1988: 398.

4 Stevens 1993: 49.

5 Cigler 1986: 98.

6 Manderson 2001: 579. 
Aboriginal peoples and third, systemic marginalisation wherein Indigenous and Muslim communities were thrown together because of white racism and discriminatory legislation.

There was a considerable degree of cultural convergence or overlap between the Muslim camel drivers and the Aboriginal communities they encountered. Like their Aboriginal counterparts, Afghan cameleers were peripatetic. As noted, the majority came from nomadic tribal clans and once here they continued to practise nomadism within discrete areas and, as with Aboriginal people, were simultaneously both 'fixed' and mobile. Other points of cultural convergence included the practice of revisiting particular areas at certain times. Aboriginal people returned to specific sites for religious reasons or to gather foodstuffs that were seasonally available, while Afghan cameleers made return journeys to mosques and other areas of significance along the various inland tracks. Each was accustomed to surviving in a climate of extreme heat and aridity where the occupants had resisted invasion and, more recently, modernisation. ${ }^{7}$ Although Afghanistan was never incorporated into the British Empire the Afghans had some experience of British invasion of their homeland. Both came from tribal cultures where the avenging of injustices with violence or murder was understood. Eating with the hands was customary; both practised the circumcision of young boys as a rite of passage; in Afghan and Aboriginal societies great respect was shown towards their leaders and elders; and they observed their obligation to provide food and other resources for newcomers and fellow countrymen.

A degree of cultural overlap also existed between northern Indigenous and Malay communities, born of their shared spatial and geographical orientation. Northern coastal Aborigines and Torres Strait Islanders, like their Malay neighbours, are salt-water people. Each comes from a marine culture where the seas between different landmasses connected, rather than divided. Malay pearl-shellers, like the Indigenous people they encountered, visited sites on a seasonal basis - each took advantage of particular resources at specific times. Both worshipped from the ground, observed strict rituals and led a lifestyle based around the temporary erection of 'camps'. Pilgrimage to sites of spiritual significance is also shared. Muslims are expected to travel to Makkah (Mecca) at least once in their lives, while Aboriginal people are obliged regularly to visit and maintain sacred sites.

A level of cultural convergence might have also contributed to the marriages or long-term partnerships between Muslim men and Indigenous women. The unaccompanied men had to look for local brides. White women sometimes married the foreign men, but most viewed them with contempt. In addition, Pamela Rajkowski suggests that 'Aboriginal women did not protest their lot, due to the way they were raised, which was in many ways similar to the expectations and duties placed on Moslem women'. ${ }^{8}$ For Muslim women obedience was a religious requirement and lack of compliance was likely to

7 Rajkowski 1995: 64.

8 Rajkowski 1995: 50-51. 
attract severe punishment. ${ }^{9}$ In Aboriginal and Muslim societies wives were often much younger than their husbands, and both cultures were polygamous. Arranged marriages were customary and in each culture a girl was betrothed to her husband at a young age, with the marriage occurring when she reached puberty. ${ }^{10}$

While they understood the Afghans and Malays to be distinct from themselves, it also appears that some Indigenous communities perceived these outsiders to be in some ways like them. Central Australian Arrernte people devised a handsign to refer to the Afghans, a circular motion of the hand around the head referring to the turbans the Afghan men invariably wore. German missionary Carl Strehlow found that another part of this hand-sign included a gesture that meant 'black', an indication that the Arrernte seemed to have perceived the Afghans as black people like them. ${ }^{11}$ Christine Choo suggests that the generally positive relations between Aboriginal people in the West Kimberley and 'brownskinned Muslims' might also have stemmed from a sense of cultural affinity borne of the fact that the 'Asians of Malay background ... had dark brown skins, not unlike the colour of Aborigines of mixed background' ${ }^{12}$ This is corroborated by research conducted by Athol Chase on north Queensland's Cape York Peninsula. In his interviews with senior men from the Lockhart River region, Chase found that what he called 'Asian Moslems, Malayans' were referred to by his informants as tungkupinta, a term that translates as 'having dark skin'. This categorisation, which could also include Aboriginal people, distinguished them as a human group that was separate from Europeans. ${ }^{13}$ As Chase remarks, coastal Aborigines welcomed 'the Asian visitors, having learned from experience that it was the Europeans who wished to dispossess them of their lands'. ${ }^{14}$

This brings us to certain 'negative' reasons for Indigenous and Muslim communities finding common cause, stemming from white imperialist attitudes. Indigenous and Muslim people were lumped together as subject peoples as a result of the widespread acceptance of Social Darwinist assumptions about the inherent superiority of whites. One manifestation of white racist ideology was the introduction of discriminatory legislation. In the case of Indigenous people, this sought to deny them any role in the future constitution of Australian society, while for non-white immigrants, it served to control and restrict their access to Australian territory. ${ }^{15}$ Other legislation introduced in Queensland (1897), Western Australia (1905) and the Northern Territory (1911) also made it illegal for white, Afghan, Malay and other non-Indigenous men to marry an Indigenous

9 Stevens 1989: 232.

10 Rajkowski 1995: 54-55.

11 Jones and Kenny 2007: 23.

12 Choo 1995: 96.

13 Chase 1981: 12.

14 Chase 1981: 8.

15 The pearl-shelling industry was so dependent on Asian indentured labourers that they, unlike their Afghan counterparts, were exempted from the provisions of the 'White Australia' policy (though they were barred from ownership of boats, businesses or land and from naturalisation). See Ganter 1998: 24. 
woman without first gaining the written permission of the Chief Protector of Aborigines. ${ }^{16}$ Ironically, the common desire of Indigenous and Muslim migrant communities to avoid the control of white police and other officials resulted in a cultural convergence that was based on shared strategies of resistance.

\section{Religion relativised}

The Afghan and Malay Muslims who came to Australia, whether as indentured labourers or 'free' migrants, had usually left countries where Muslims were in the majority. Their religious practice in their homelands may have been 'automatic' or 'unreflective', but in Australia they were cultural, religious and social minorities and were thus liable to be drawn to reflect on their religious identity. ${ }^{17}$ What had formerly been a conventional identification might assume in the new environment a special personal significance, a development that could have a significant impact on the way Muslim fathers and husbands interacted with their Australian-born families.

Nameth Allick Khan, for example, who came to Australia in 1892, and died in Marree in 1950 at the age of 84 was a devout Muslim and raised his children according to the Islamic religious and cultural traditions of his homeland. His granddaughter, Marilyn/Fatimah, believes that her grandfather's staunch adherence to his traditions was in part a reaction to the novelty of his situation, and to the rapidly changing socio-economic environment, 'It would have been hard for everybody at that time, things were changing. Their lives were changing before their eyes and they really had no control over $i t^{\prime}{ }^{18}$ Experiencing the rise and demise of the Afghan camel carting industry and the subsequent decline in the Afghan cameleer community, 'Grandfather must have been frightened too', reflects Marilyn's sister, Beatrice Boerkamp (nee Khan):

like all the old Afghans that were up there [in Marree] that had created this new world for themselves, but [were] still really steeped in their own way. It must have been so frightening that they lost their own country, and they were now ready to lose what they came here to make ... I guess that's why they hung on so much [to their Islamic traditions]. ${ }^{19}$

Beatrice, like her siblings, was given both an English and an Afghan name as a child. Known familiarly as Zanzibar, her Peshawar-born ${ }^{20}$ grandfather 'was a very strict disciplinarian. He was a Muslim, and his family would live the life of a Muslim as long as he was alive. And we did, oh believe me' ${ }^{21}$ Other

16 Stephenson 2007: 62-81.

17 Bouma, Daw and Munawar 2001: 59, 69.

18 Marilyn Robertson in interview with the author, 9 June 2007, Adelaide, South Australia.

19 Beatrice Boerkamp in interview with the author, 9 June 2007, Adelaide, South Australia.

20 Peshawar is located on the edge of the Khyber Pass, near the border of Afghanistan. It is now a regional city in Pakistan, but prior to Pakistan's creation in 1947, Peshawar was part of what was considered to be the North-West Frontier Province of British India.

21 Beatrice Boerkamp in interview with the author, 9 June 2007, Adelaide, South Australia. 
Indigenous-Muslim descendants recount similar experiences. Mona Wilson (nee Akbar) described her Peshawar-born father as a devout follower of Islam who 'kept his faith 'till the day he died'. ${ }^{22}$ Similarly, the late Aboriginal-Malay Septu Brahim stressed that his father 'was a strict Moslem ... [who] practised it very, very strongly'. ${ }^{23}$ In these and many other Indigenous-Muslim families, seeing their father at prayer was a common occurrence. As a young child Joanne Nasir remembers walking in on her Muslim Indonesian grandfather while in sujud, an Arabic word meaning prostration to God. Muslims prostrate while facing Makkah (Mecca), with their hands, forehead, nose, knees and all toes touching the ground. Unaware that her grandfather was engaged in ritual prayer, Joanne assumed 'he [was] looking for something under the bed'! ${ }^{4}$

But generalisation is difficult: other descendants noted that their fathers were less committed to their religion than their Muslim peers. Born on Thursday Island in 1924, Eva Salam Peacock ${ }^{25}$ is the daughter of a Makassan father and Torres Strait Islander mother (of Islander, Danish and Sri Lankan descent). According to Eva her father 'wasn't a very religious man. I didn't see him do all the things that religious Muslims do' ${ }^{26}$ Speaking of her Muslim step-father, who came to Broome from Singapore in the 1930s, Sally bin Demin recalls, 'my stepfather never prayed that much' ${ }^{27}$ This apparent variety in religious devotion is demonstrative of the fact that religious minorities negotiate their relationship with the dominant society in a number of ways. In my research some sought to manage the transition to a new life and culture by abandoning their religious practises altogether; others practised their faith in private; some expected their wives and children to become Muslim, while others took a more ecumenical approach and lived happily in multi-cultural and polytheist households and communities.

Family anecdotes indicate that most Afghan and Malay fathers were accepting of their wives' and children's adoption of a non-Muslim faith. Eva Salam Peacock's experiences are typical: 'Dad was a Muslim but he didn't mind if we were Catholic. He didn't mind us going to a Catholic school' ${ }^{28}$ This attitude might be partly due to the Qur'anic injunction, 'let there be no compulsion in religion'. 'Ali' (a pseudonym), a Singapore-born Muslim Malay who came to Broome in 1950 to work in the pearl-shelling industry, had this to say: 'No, that fella want to go Catholic, that's his business, his life. He want to go Muslim, his life ... According to my religion, wrong thing to push people ... I respect the other people'. ${ }^{29}$ Ali's Aboriginal Catholic wife 'Patricia' agrees, commenting:

22 Mona Wilson in interview with the author, 21 November 2005, Kyneton, Victoria.

23 Brahim 2000: 51.

24 Joanne Nasir in interview with the author, 17 December 2007, Darwin, Northern Territory.

25 Salam (or salaam) means 'peace' in Arabic. Salaam 'alaikum is a universal greeting with which Muslims address each other, meaning 'peace be upon you'.

26 Salam Peacock 2004: 280.

27 Sally bin Demin in interview with the author, 5 September 2006, Broome, Western Australia.

28 Salam Peacock 2004: 280.

29 'Ali' (a pseudonym) in interview with the author, 15 July 2005, Broome, Western Australia. 
'Yeah, well he's got his - I don't interfere with his religion or when he goes out and prays or whatever. He doesn't interfere with mine, so just leave it at that and everyone's happy that way. No forcing business, you know' ${ }^{30}$

The Aboriginal wives of Afghan men had similar experiences. Esther Kite was married to her late Afghan-Aboriginal husband for more than 20 years. In our conversation she described her husband as a 'strict' Muslim who always 'kept his religion'. He avoided pork, prayed regularly at home, treated his Peshawarborn father's Qur'an reverentially and instructed their children how to say 'the Afghan prayer'. Notwithstanding this he was very accepting of his family's Methodism. As Esther recalls, 'in those days [late 1950s to early 1960s] we didn't have anywhere to go, like Mohammadan church, but the kids used to go to a Methodist church, all the children were baptised in the Methodist church' ${ }^{31}$

Muslim husbands were perhaps also disposed to recognise their wives' and children's religious beliefs because they were in the minority. In the early twentieth century when there were relatively strong Afghan and Malay communities in Australia, the men held firmly to their Islamic beliefs and traditions. Over time, with a decline in the number of Muslim arrivals in Australia, and an increase in the rate of inter-marriage between Muslims and non-Muslims, the men's Islamic beliefs tended to become more of a private affair. Joanne Nasir recalls that her Muslim Indonesian grandfather:

was of the belief that you're in somebody else's country, and he married into a different culture, so he was willing for his children to make their own decision ... he allowed the children to make the choice, whether they became Catholic, the Uniting Church, Muslim, Hindu - but at the same time he followed his religion very much within himself. ${ }^{32}$

But, again, generalisation is difficult: not all Muslim grand/fathers tolerated their families' religious beliefs. Some expected their Aboriginal wives and children to accommodate, if not fully embrace, Islam. Aboriginal-Malay Septu Brahim recalled that during his upbringing his father's Muslim religion predominated:

My [Catholic] mother was brought up with Irish and Germans [at Beagle Bay mission near Broome] and then she had the Aboriginal culture too. She had two cultures. But my father ... he only had the one culture ... and my mother had to fit in. Yes, we never ate pork or bacon and every Thursday night after he finished work ... he'd read the Koran and we'd get into it. If any visitors came, he'd make them sit there and listen to him praying. ${ }^{33}$

30 'Patricia' (a pseudonym) in interview with the author, 15 July 2005, Broome, Western Australia.

31 Esther Kite in interview with the author, 12 December 2007, Alice Springs, Northern Territory.

32 Joanne Nasir in interview with the author, 17 December 2007, Darwin, Northern Territory.

33 Brahim 2000: 51. 
Septu's father was profoundly opposed to his son's christening as a Catholic, particularly when it occurred without his knowledge or consent. According to Septu he was a toddler (in the early 1930s in Port Hedland) when a visiting Catholic priest was conducting christenings at the local church. He and some other neighbourhood children were christened, an event that was casually communicated to Septu's father by an unwitting co-worker. According to Septu his father 'just dropped everything and blew his top and went out the back door, came racing home and went berserk'. ${ }^{34}$ Aboriginal-Malay sisters Semah and Halimah Mokak's baptisms were also carried out in secret. Semah recalls that her Aboriginal mother took her and her sister to be baptised while their Malaysian Muslim father was out at sea working on a pearl-shelling lugger. Semah's mother was obliged to have her daughters' baptism performed in a clandestine fashion because, according to Semah, her Muslim 'father had this really strong hand on all of us about being Muslims and we were Muslims and that was it' ${ }^{35}$

Some stratagems for securing a proper religious education were decidedly opportunistic. Semah, Halimah and the other Mokak children have vivid memories of their school holiday visits in the 1960s to the Daly River (about 140 kilometres south of Darwin), where a white South African imam (someone who leads the prayers during Islamic gatherings) who was a friend of the family's resided. As Halimah recalls:

Well [the imam], I think he was a bit of a shady sort of a character, but I don't know - he was a friend of a very dear old lady friend of ours, who used to look after this community with the Malak Malak people on the Daly River. So we used to go on holiday there every school holidays, and so that's where Dad met him. So he was then appointed our religious instruction imam, and so we would have to - in the bush, with all the local kids all peering through the grass - we'd have to put down our little mats, and what I strongly remember, we used to laugh so much because the imam had his two big toes missing, so he didn't have balance. When he used to go down to initiate his prayer, we were all behind him, so we would just start laughing, we just couldn't stop laughing, you know - we had to try and be serious. So, we were learning all this, and we'd do the Islamic chant, La illaha ill Allah [There is none worthy of worship except Allah] and then, you know, you'd look around and you'd see all these little eyes in the bush, doing the same thing, all the local Malak Malak kids, and it was just so funny. ${ }^{36}$

From all accounts the South African imam was a rather eccentric character. To this day Semah and Halimah are not sure what prompted him to leave South Africa, or why he was living at the Daly River Aboriginal mission.

34 Brahim 2000: 52.

35 Semah Mokak-Wischki in interview with the author, 15 August 2006, Brisbane, Queensland.

36 Halimah Mokak in interview with the author, 14 August 2008, Melbourne, Victoria. 
Perhaps as important as the content of these lessons was the impulse behind them, the evident commitment to educating the children into a tradition that transcended place and tribe. Born in Marree in 1941, Aboriginal-Afghan Dean Mahomed was instructed in the ways of Islam by his great uncle Mullah Assam Khan (a mullah being one learned in Islamic theology). Dean recalls that he and the other Marree 'Ghantown' boys prayed 'twice a day, morning and before sundown'. He continues:

When we was kids we had to go there, you had to wash - the bore drain went through the chapel [mosque], and on the duck board you had to wash your hands and wash your feet before you went in there ... You had to go in barefoot and you went in there and you said 'La illaha ill Allah, Mohammad rasul Allah'. ${ }^{37}$ Mullah Assam Khan was in charge of all of us as we prayed ... and he said, 'My boy you've got to wash your feet and wash your hands before we go in that Mosque'. ${ }^{38}$

The repetition of these rituals across the outback, inside or outside nascent Muslim communities, surrounded by amused or uncomprehending onlookers, not only served to produce a sense of distinct family at the time: remembered generations on, this determination to communicate religious values strikes the descendants as admirable. It is out of respect for the spirit of those initiatives that they self-identify as kinverts.

\section{Multicultural community}

People removed from familiar support networks and beset by cultural and socioeconomic difficulties in a new and strange land tend 'to seek support among those with whom they share some commonality'. ${ }^{39}$ In Australia, Afghan and Malay Muslims each created social and religious connections with fellow countrymen and other Muslims. The various 'Ghan' towns or camps dotted throughout inland Australia played an important role in the Afghan communities' negotiation of a new life in a new country. They were places of religious guidance, friendship, support and where recent arrivals could learn from the more established Afghans how to navigate the way through an alien system and society. Ghan camps and, in particular, urban mosques also became important places of refuge for elderly Afghans who had little employment opportunities following the demise of the camel carting industry.

The 'Malaytowns' or quarters in north Australian coastal communities were also sites where ethnic and religious identities could be sustained and renewed. In the pearling industries of Broome, Darwin and Thursday Island there were both transient populations of indentured Malay workers, who were focused on earning money and returning to their homelands, and a resident Malay

37 There is none worthy of worship except Allah and Muhammad is his Messenger.

38 Dean Mahomed in interview with the author, 23 April 2007, Port Augusta, South Australia.

39 Bouma, Daw and Munawar 2001: 59. 
population with strong links to the local Indigenous community..$^{40}$ Sally bin Demin recalls seeing the Malay men in Broome's Malay quarters engaged in silat, a martial art form practiced throughout the Malay Archipelago. ${ }^{41}$ Others, including sisters Majunia and Rose bin Swani (the daughters of a JapaneseAboriginal mother and Singapore-born Muslim Malay father), have very fond memories of the wonderful smells of the delicious food, including rice, curries and satays that the young Malay men shared with them and their siblings. ${ }^{42}$ Mark bin Bakar was raised by his Kitja Aboriginal mother and Malay step-father (who came to Australia from Singapore in 1950). Growing up in Broome in the 1960s, he recalls his frequent visits to the Malay lodgings on the foreshore:

I felt very free when I went up to the Malay quarters ... I used to run through the men's quarters that were laid out like an army camp with lines and lines of beds. I felt at home there. Dad used to take us to the Malay quarters prior to going down to the creek for fishing and crabbing. We'd drag all these Malay boys with us to the creek and would come back with all this fish ... The kitchen there was a big communal one and ... there were big pots of curries and chillies which gave off a beautiful aroma. $^{43}$

Disagreements within Muslim communities in Australia occurred of course, but Malays and Afghans also supported their fellow countrymen in a variety of ways. Many Afghans and Malays offered financial support to newcomers, or a meal and a place to sleep for those who needed them. Majunia and Rose bin Swani recall that when their Malay father died (in Broome in 1975), the younger itinerant Malay pearl-shell workers, who looked upon him as a father, regularly came to their aid. The young Malay men helped the bin Swani family with odd jobs, brought them cooked meals and generally supported his widow and adolescent children in any way they could. ${ }^{44}$ In Darwin Joanne Nasir noted that her Muslim grandfather was 'very considerate to his fellow Indonesians and relations. He offered his family and his property and everything else, and if anybody was travelling through, [the family's 20 acre property] was their meeting ground' ${ }^{45}$ In the 1920s, a number of Afghan men came to the aid and support of Peshawar-born Jack Akbar, who was fleeing Western Australia's Chief Protector of Aborigines for engaging in an 'illicit' affair with his Aboriginal partner Lallie. According to their daughter Mona Wilson (nee Akbar) it was because of the help offered by her father's 'people', and a dear friend in Farina (in South Australia), that her parents made their way safely to Adelaide, where they were married. ${ }^{46}$

40 Ganter 1999: iii.

41 Bin Demin 2007: 33.

42 Majunia and Rose bin Swani in interview with the author, 3 September 2007, Broome, Western Australia.

43 Bin Bakar 2002: 44.

44 Majunia and Rose bin Swani in interview with the author, 3 September 2007, Broome, Western Australia.

45 Joanne Nasir in interview with the author, 17 December 2007, Darwin, Northern Territory.

46 Mona Wilson in interview with the author, 21 November 2005, Kyneton, Victoria. 
Afghan and Malay Muslims created their own ethnic and religious networks of support, but this did not exclude an engagement with the wider Australian community. Some Muslims, particularly in the early days, had little contact with non-Muslim society, but over time the majority became active participants in their local communities. Some white Australian men worked side by side with the Afghans, while others worked closely with Malay men. In the event that an Afghan or Malay required a character reference, it was often white storekeepers and other influential townsfolk who did them this favour. ${ }^{47}$ In Broome Anthea Demin, of Aboriginal-Malay heritage, noted that the local Muslim men have been long supporters of the town's church and school, through their contributions to fundraising and other events. ${ }^{48}$

Festivals held at the end of the month-long fast of Ramadan were eagerly attended by Muslims and non-Muslims alike. The holy month of Ramadan is the ninth month of the Muslim lunar calendar, during which Muslims abstain from food, water and sexual relations each day from sunrise to sunset. The festival marking the end of Ramadan is known in Arabic as Eid ul-Fitr. Europeans and others living near Afghan communities knew the huge communal feasts as 'Afghan Christmas'. Curries, rice, fruit and sweets were served, with dancing and singing, and gifts given to the Afghan, white Australian and Aboriginal children. ${ }^{49}$ In Broome the Malay Muslims also invited non-Muslims to celebrate 'Malay Christmas' or Hari Raya, the Malay term for Eid ul-Fitr. The Malays not only fulfilled their religious obligations, they also contributed to the town's social fabric. In Mark bin Bakar's words:

We used to have it at Malay quarters and everyone went to it, the whole town went to it. It didn't matter if you were white or Black, everyone celebrated Hari Raya. For every one Malay there were probably two non-Muslims. ${ }^{50}$

The strong family and community bonds extant in 'Ghan' camps and 'Malay towns' were held together by shared ethnic, national and religious ties but also, at times, a forced alienation from white Australian society. ${ }^{51}$ Interviewees Halima binti Hassan Awal and 'Patricia' recall growing up in the 1950s (on Thursday Island and in Broome, respectively) when they and their families were subjected to petty apartheid. They could not sit with the white townsfolk at the local cinema, were obliged to frequent separate public facilities and were even treated at the hospital apart from the white patients. ${ }^{52}$ Close-knit IndigenousMuslim families and communities did not result solely from the desire to be among kindred spirits, they also formed a bulwark against an often hostile white Australia.

47 Rajkowski 1987: 52.

48 Anthea Demin in interview with the author, 5 September 2006, Broome, Western Australia.

49 Stevens 1989: 193.

50 Mark Bin Bakar in interview with the author, 14 July 2005, Broome, Western Australia.

51 Stevens 1989: 260.

52 Halima binti Hassan Awal in interview with the author, 30 March 2005, Brisbane, Queensland. 


\section{Making common cause}

Generalisations need to be treated with circumspection. The permutations of accommodation generated within a relatively small group of IndigenousMuslim families are remarkable. They not only influenced the internal family dynamic and the face the family showed to its immediate neighbours. They could in exceptional circumstances elicit non-stereotypical behaviour from the wider population. The all too evident vulnerability of the men and women who came together across laws and cultures was dramatically exposed by the operations of the law. At the same time, the tenacity, uprightness and decency of individual Muslim men in this situation occasionally had the power to produce an empathy that, in another permutation, broke down barriers between races and creeds - and this potential, while of limited historical significance, is of considerable symbolic importance to the descendants of such events.

The story of the Aboriginal-Indian Sahanna family is a case in point. The late Kemel Ngummurra Si Hanna (Jack Sahanna) was born in about 1934 at Moonlight Valley station, more than 200 kilometres south-west of Wyndham (in north-west Western Australia). As a nine year old Jack, the son of an Indian father and Aboriginal mother, was forcibly taken from his home and family to Beagle Bay mission (about 120 kilometres north of Broome). His younger sister Meriam (Mary Ann) was also taken away. According to Jack's daughter 'Ruth' (a pseudonym), it is not clear whether Jack spoke his mother Mary's east Kimberley language, or his father's tongue when he arrived at the mission, but none of the officials there could understand him. ${ }^{53} \mathrm{He}$ had to learn English, eventually forgetting his original tongue and, in the process, becoming 'estranged from his family and background'..$^{54}$

In the late 1920s Jack's father Sianna Sindhi, or Sahanna, had started a cattle run, Moonlight Valley station, on the east Kimberley's Salmond River. When Sahanna first came to the area a local Aboriginal man Tommy showed him where he could 'sit down' on his ancestral lands. Accompanied by his partner Daisy and their two daughters Mary and Winnie, the Aboriginal family moved to Sahanna's station..$^{55}$ It was an arrangement that benefited both parties. Sahanna could not prosper without cheap Aboriginal labour and local Aboriginal families were guaranteed a livelihood while remaining on their own country. In the 1930s Sahanna, who was now in his sixties, fathered two 'mixed-race' children. Jack was born to Mary, and a few years later, a daughter was born to Mary's sister Winnie. In Aboriginal and Muslim cultures, as we have seen, wives were usually considerably younger than their husbands. In Muslim societies a man had to work for years to save enough money to support his young wife, while Aboriginal men had to go through initiation before they were deemed ready to

53 'Ruth' (a pseudonym) in interview with the author, 2 September 2006, Broome, Western Australia. Unless otherwise indicated, all subsequent quotations are taken from this interview.

54 Ganter 2006: 185.

55 According to Regina Ganter (who also discusses the Sahanna family in her Mixed Relations), it is not clear if the lease was in Sahanna's name or whether it was held through a dummy owner. See Ganter 2006: 180. 
take a wife. In each culture polygyny was practised and, from an Aboriginal and Muslim perspective at least, Sahanna's sexual relationships with two younger women were acceptable.

But not everyone approved of Sahanna's cross-cultural partnerships. Following Jack's birth Sahanna came under increased scrutiny by Western Australian officials. As a so-called 'Asiatic', Sahanna was not permitted to employ Aboriginal labourers or 'cohabit' with Aboriginal women. Restrictions upon their employment of Aborigines denied 'Asians' (including Afghans) the most common pretext used by white men for having Aboriginal women on their premises. According to Regina Ganter's research, a local constable suggested to Sahanna in 1937 that he employ a white manager who, she claims, 'would safeguard the kind of morality that could be officially sanctioned with a permit to employ Aboriginal labour'. ${ }^{56}$ In 1943 Sahanna employed a white stockman and a permit to employ Aborigines was subsequently issued. By this time there were at least three children and a dozen adult Aboriginal residents at Moonlight Valley. ${ }^{57}$

Sahanna no doubt assumed the presence of Aborigines on his station was now covered by the employment of the white manager. Unfortunately, a result of the white man's actions was the further intrusion of the Aboriginal protection bureaucracy into the Sahanna family's affairs. The white manager shot and killed Mary's Aboriginal husband and Sahanna, along with the Aboriginal residents, was taken to Perth as a witness in the trial. Ganter notes that while he was in Perth, Sahanna came under pressure from Western Australian Commissioner of Native Affairs, Frank Bray. He was threatened with prosecution for 'cohabitation' unless he consented to the removal of his children and agreed to pay maintenance for their upkeep to the department. ${ }^{58}$

Prior to his removal Jack had very fond memories of time spent with his father. 'Ruth' recalled hearing her father talk about his experiences, which included riding camels, rounding up cattle and going out 'with his father all the time. He spent a lot of time with him while his mum was staying at camp'. Other recollections confirm that Sahanna introduced his son to the Islamic faith. Jack recalled waking up early and accompanying his father on a camel to the top of a nearby hill, from which they would say their prayers. He also remembered not eating pork.

According to 'Ruth', before Jack's removal Sahanna had plans to send his son away to school. He wanted Jack to be educated, to make something of his life: 'he had to be somebody, and he remembered his dad always telling him, "I'm going to send you away because you're going to be somebody one day"'. It remains unknown how Jack's Aboriginal family would have responded to this. What family lore does recount is the obvious agency they exhibited in their attempts

56 Ganter 2006: 181

57 Bottrill c1992: 5.

58 Ganter 2006: 181. 
to prevent the Aboriginal protection bureaucracy from taking Jack away. Jack's Aboriginal grandmother painted him with a black muddy substance so that the tracker sent to locate and remove him would not detect him among the other so-called 'full-blood' children. On the tracker's fourth attempt (while almost all of Moonlight Valley's residents were at the Perth court case), he discovered Jack because it was a rainy day and the black substance was dripping off him. Many years later this same tracker relocated Jack as an adult and apologised for removing him from his family. 'Ruth' recalled his visit as an adolescent and the way her 'Dad was just sitting there, tears were just running down [his face]'.

White interference in this case both helped and hindered the Sahanna family. The intrusion of the Western Australian Aboriginal protection bureaucracy broke the family apart. On the other hand, it also provoked empathetic behaviour among the authorities: in advising Sahanna how to circumvent the restrictions placed on his employment of (and cohabitation with) Aborigines, the local constable sought to help keep the family together. Ann McGrath suggests that the unofficial advice that some police and other influential whites gave 'mixedrace' couples (about impending raids or ways to avoid the imposition of a removal order) complicates the somewhat exaggerated 'and misleading image of a general populace wholeheartedly enthusing about "White Australia". ${ }^{59}$ In any case, the vicissitudes of the Sahanna family become a microcosm of the struggle for an Australian identity which continues to preoccupy politicians and pundits today. Heir to this complex history of resistance and loss, kinverts not only acknowledge a legacy of pain: they inherit a far more nuanced, sophisticated and realistic understanding of the complexities of identity formation in this country than is presented in either our history books or the media.

\section{Kinversion and alternation}

Women feature prominently among the story-tellers I have interviewed. Although they narrate the experiences of male forebears, they inflect their accounts with an irony that is both affectionate and critical. It is likely that the stories they tell have come down to them largely from their mothers. The characterisation of the men's behaviour as lying along a spectrum between strict orthodoxy and relative tolerance of other ways reflects the experience of those who suffered the consequences of these different attitudes. They also suggest that women's experiences and views, while they may have been respected, were not necessarily well understood or probed by the men folk. The women in my interviews were recounting the experiences of men but, in the way they told the stories, and in the sense they communicated of knowing more than they let on, they were also relating women's stories - the experiences of women coming to terms with, and circumventing patriarchal attitudes.

Thus, while Afghan and Malay descendants alike spoke of the way their Indigenous mothers became Muslim after marrying their husbands, few

59 McGrath 2003: 46. 
identified with Islam spiritually and theologically. The often mission-raised women tended to identify with various Christian denominations and, while they adopted particular Islamic rituals or behavioural norms during their married life, this was perhaps more an indication of their preparedness to accommodate their husbands' beliefs and practices, than a desire to become religiously practising Muslims. Indigenous wives' adoption of Islam helped create a sense of unity within their racially, culturally and religiously diverse families. In the words of Aboriginal-Malay descendant Semah Mokak, 'I think Mum just, you know, she was a Muslim to please Dad really'. In an interview with Dilara Reznikas, Semah's sister Halimah characterised their mother's (cultural) acceptance of Islam in these terms: 'My mother was a Catholic woman and she converted to Islam, but she didn't practice Islam as such ... We were the ones that used to practice Islam, but she still used to go to church with her mother' ${ }^{60}$

Significantly, taking on the new religious and ideological codes of their husbands did not include the women forgoing previously held beliefs and commitments. While Aboriginal and Torres Strait Islander women adhered to many Islamic religious and cultural practices during their married lives (at least in the presence of their husbands), these did not replace their prior held convictions. The kind of identity change they exhibited could be described as one of 'alternation'. According to Richard Travisano, unlike conversion, alternation refers to a less radical form of religious and ideological change which is much more inclusive of former commitments. ${ }^{61}$ Rather than replacing the old with the new, they are combined. ${ }^{62}$ Indigenous wives exercised agency in deploying particular worldviews and identities in particular contexts. In some environments it was appropriate to utilise a specific set of beliefs and practices, while in other situations an alternative set of religio-cultural traditions was foregrounded.

Indigenous women who entered partnerships with Afghan and Malay Muslim men accommodated at least three religio-cultural systems. Unless they were completely cut off from their country and kinfolk at a very young age the women had access to the beliefs and practices of their local tribe or language group. These were usually enmeshed with the various Christian traditions they were exposed to on reserves and missions. Such introduced beliefs were, in turn, combined with their Muslim husbands' religious and ideological practices. Another factor to bear in mind, however, is that many Aboriginal and Islander women who married Muslim men had, themselves, been raised by Muslim fathers or step-fathers. Such women combined or alternated between a further layer of cultural, ethnic, national and religious loyalties. This raises the question of whether we might more accurately characterise these women as kinverts or as alternators, individuals engaged in an ongoing process of 'alternation'. Kinversion is a broad category that includes growing up in a Muslim ambience

60 Halimah Mokak in interview with Dilara Reznikas, date unknown. Partial transcript in the possession of the author.

61 Travisano 1970: 600-606.

62 Wohlrab-Sahr 1999: 353. 
and kinverts' proclamation of a Muslim identity is inextricably bound up with their desire to honour their grand/ parents or other ancestors. As such, kinversion does not refer specifically to the particular act of integration or accommodation that Indigenous women undergo in marriage. This form of alternating identity change might best be understood as a discrete sub-set of kinversion.

In this sense, kinversion is both an historical and a cultural category. It embraces the behaviour of many Indigenous women marrying Muslim men, but it also applies to the descendants of these unions. Aboriginal-Afghan descendants are tremendously proud of their heritage. They want their forebears' immense contribution to Australia's material wealth and cultural landscape to be acknowledged and appreciated. But, in common with Indigenous-Malay kinverts, honouring the memories of their forefathers does not necessarily extend to reclamation of their religious beliefs. As Philip Jones, senior curator at the South Australian Museum, remarks: 'The [Afghan] descendants today ... there probably isn't any religious gesture they make, other than generally steering away from pork. But if Ramadan came around, I don't think it would impinge on their lives any longer' ${ }^{63}$ This does not mean, however, that the kinverts I met are any less attached to their Muslim identity, even if only in symbolic terms.

Many Indigenous-Muslim kinverts imbibed Islamic religio-cultural beliefs and practices as a natural part of their upbringing in a Muslim household. Others, as we have seen, were given more formal religious instruction. My interviews with Aboriginal and Torres Strait Islander Australians who grew up in Muslim households and communities have revealed unique and profound insights into the religious and cultural traditions of their Islamic families and forebears. But can they be characterised as Muslim? The vast majority of descendants are not interested in taking on Islam in any strict sense. This is why I have proposed the terms kinvert and kinversion. They are labels that I hope preserve and pay homage to the descendants' connection to an Islamic orientation, but differentiate their experiences from those of Muslim converts. Religious conversion usually involves drastic transformations in one's life. Converting to a (new) religion often entails a complete change of allegiance from one source of authority to another. ${ }^{64}$ But the Indigenous-Muslim descendants I have encountered combined Islamic and Christian practices and traditions in their daily lives: they celebrated the end of Ramadan and Christmas; they were taught to recite passages from the Qur'an and the Bible, how to perform salat (the daily prayers of Islam) and sing Christian hymns.

In light of this, the question of whether or not Indigenous-Muslim descendants are Muslim seems a little simplistic. To answer in the negative disregards the immensely significant role that Islamic beliefs and practices have played in their daily lives. But nor do the vast majority of Indigenous-Muslim descendants I have met necessarily consider themselves members of the ummah, or international community of believers. Whether or not they are Muslim is a question that only

63 Philip Jones in interview with the author, 4 December 2007, Adelaide, South Australia.

64 Travisano 1970: 600. 
individual descendants can answer. To judge from the evidence presented here, responses will be highly personal. When I asked Halimah Mokak if she would call herself a Muslim she replied: 'Well no, but I would say I was brought up a Muslim because it's just been involved in all of my daily life' ${ }^{65}$ Growing up with what he described as 'a very strict Catholic upbringing, but also the disciplines of the Islam faith', Aboriginal-Malay Mark bin Bakar stressed that 'the convergence of the two religions' made him who he is today. ${ }^{66}$ Another Aboriginal-Malay, Johari bin Demin, also possesses this doubled cultural and religious identity: 'I've had, I suppose, a Catholic influence throughout my life, but I do feel some affinity with Muslims and I can understand [them], I can connect with them and I'm aware of what their issues are' ${ }^{67}$

Aboriginal-Afghan descendants espouse a similar view. 'Ruth' suggests that even though her father Jack (who was nicknamed 'the Ghan' in Broome) was baptised at Beagle Bay as a Catholic, 'he never forgot who he was back then. He always knew his father was a Muslim and he remembered himself being part of that, but that never clashed with having to become a Catholic'. Shirley Wilson's stance is similar: 'We were brought up with a Christian upbringing, plus the Muslim thing at home, part and part' ${ }^{68}$ This dual identity is eloquently summed up by her sister Mona: 'So I sit on two chairs, you know. I sit on the Christian chair sometimes and on the Muslim chair sometimes. I sit on the Afghan chair sometimes and I sit on the Aboriginal chair sometimes. It depends' ${ }^{69}$ This is a statement of considerable wisdom and wit. It captures the formidable resourcefulness which informs the everyday lives of kinverts. Kinverts belong neither to the past nor to the present. They insist on the kinship of past and present, on the value of a continual accommodation of different histories in building a sense of self in the present. And this attentiveness to the way identities are negotiated when there is good will and commitment to human values is not only a personal legacy: it defines an attitude to the world that translates into principled action designed to communicate the exceptional contribution kinversion can make to the larger projects of thinking who we are, how we narrate ourselves, and where we propose to 'sit'.

\section{References}

\section{Primary source}

Bottrill, AM c1992, “Sahanna”: Sindhi camelman, soldier, sandalwooder, squatter', unpublished collection of notes on Sahanna by Gus Bottrill.

65 Halimah Mokak in interview with the author, 14 August 2008, Melbourne, Victoria.

66 Bin Bakar, Mark in interview with the author, 14 July 2005, Broome, Western Australia.

67 Johari bin Demin in interview with the author, 4 September 2006, Broome, Western Australia.

68 Shirley Wilson in interview with the author, 8 April 2006, Perth, Western Australia.

69 Mona Wilson in interview with the author, 21 November 2005, Kyneton, Victoria. 


\section{Secondary sources}

Bin Bakar, Mark 2002, 'Mark "Mary G" Bin Bakar', in Why not Broome, Noel Trevor (ed), Noel Trevor Enterprises, Cable Beach, WA: 37-63.

Bin Demin, Sally 2007, Once in Broome, Magabala Books, Broome.

Bouma, Gary D, Joan Daw, and Riffat Munawar 2001, 'Muslims managing religious diversity', in Muslim Communities in Australia, Abdullah Saeed and Shahram Akbarzadeh (eds), University of New South Wales Press, Sydney: 53-72.

Brahim, Septu 2000, 'Recollections of the Early Days', in Those Who Remain Will Always Remember: An Anthology of Aboriginal Writing, Anne Brewster, Angeline O'Neill and Rosemary van den Berg (eds), Fremantle Arts Centre Press, Fremantle WA: 46-57.

Chase, Athol 1981, “"All Kind of Nation”: Aborigines and Asians in Cape York Peninsula', Aboriginal History 5(1): 7-19.

Choo, Christine 1995, 'Asian men on the West Kimberley Coast, 1900-1940', Studies in Western Australian History 16: 89-111.

Cigler, Michael 1986, The Afghans in Australia, Australasian Educa Press, Blackburn, Victoria.

Ganter, Regina 1998, 'Living an Immoral Life: coloured women and the paternalistic state', Hecate 24(1): 13-40.

- 1999, 'Editorial: Asians in Australian history', Queensland Review 6(2): i-iv.

- (with contributions from Julia Martínez and Gary Lee) 2006, Mixed Relations: Asian-Aboriginal contact in North Australia, University of Western Australia Press, Crawley, WA.

Jones, Philip and Anna Kenny 2007, Australia's Muslim Cameleers: Pioneers of the Inland 1860s-1930s, Wakefield Press, Kent Town, SA.

Loois, Vivienne 1988, 'Afghans and Indians in Western Australia', in Asian Immigrants to Western Australia 1829-1901: The Bicentennial Dictionary of Western Australians, Volume v, Anne Atkinson compiler, University of Western Australia Press, Nedlands, WA: 397-402.

Manderson, L 2001, 'Malays', in The Australian People: An Encyclopedia of the Nation, Its People and Their Origins, James Jupp (ed), Cambridge University Press, Cambridge: 579-80. 
McGrath, Ann 2003, 'The golden thread of kinship: mixed marriages between Asians and Aboriginal women during Australia's Federation era', in Lost in the whitewash: Aboriginal-Asian Encounters in Australia, 1901-2001, Penny Edwards and Shen Yuanfang (eds), Humanities Research Centre, Australian National University, Canberra: 37-58.

Rajkowski, Pamela 1987, In the Tracks of the Camelmen, Angus \& Robertson, Sydney.

- 1995, Linden Girl: A Story of Outlawed Lives, University of Western Australia Press, Nedlands, WA.

Salam Peacock, Eva 2004, 'Voices from Torres Strait: Eva Salam Peacock', in Navigating Boundaries: The Asian Diaspora on Torres Strait, Anna Shnukal, Guy Ramsay and Yuriko Nagata (eds), Pandanus Books, Canberra: 278-281.

Stephenson, Peta 2007, The Outsiders Within: Telling Australia's Indigenous-Asian story, University of New South Wales Press, Sydney.

Stevens, Christine 1989, Tin Mosques E Ghantowns: A history of Afghan Cameldrivers in Australia, Oxford University Press, Melbourne.

- 1993, 'Afghan camel drivers: founders of Islam in Australia', in An Australian Pilgrimage: Muslims in Australia from the Seventeenth Century to the Present, Mary Lucille Jones (ed), Victoria Press, Melbourne: 50-62.

Travisano, Richard V 1970, 'Alternation and conversion as qualitatively different transformations', in Social Psychology Through Symbolic Interaction, Gregory P Stone and Harvey A Faberman (eds), Xerox College Publishing, Waltham, Mass: 594-606.

Wohlrab-Sahr, Monika 1999, 'Conversion to Islam: between syncretism and symbolic battle', Social Compass 46(3): 351-362. 